\title{
Pengaruh Penggunaan Software Treker Terhadap Hasil Belajar Fisika Mahasiswa Pada Pokok Bahasan Viskositas Fluida
}

\begin{tabular}{|c|c|}
\hline & $\begin{array}{c}\text { Ahmad Fahrudin } \\
\text { Akademi Maritim Cirebon, Indonesia, } \\
\text { fahrudinahmad63@gmail.com }\end{array}$ \\
\hline $\begin{array}{l}\text { ( ) access } \\
\text { *Penulis Korespondensi }\end{array}$ & \multirow{5}{*}{$\begin{array}{l}\text { ABSTRAK } \\
\text { Penelitian ini bertujuan untuk mengetahui pengaruh penggunaan software } \\
\text { treker terhadap hasil belajar fisika mahasiswa pada pokok bahasan } \\
\text { viskositas fluida. Sampel dalam penelitian ini yaitu mahasiswa semster satu } \\
\text { prodi teknika Akademi Maritim Cirebon. Metode penelitian yang digunakan } \\
\text { yaitu one group pretest-posttest design dengan teknik analisis paired sample } \\
\text { t-test. Sebelum dilakukan pembelajaran menggunakan menggunakan } \\
\text { software treker untuk menganalisis vidio viskositas fluida, mahasiswa } \\
\text { diberikan pre-test untuk mengetahui kemampuan awal mahasiswa mengenai } \\
\text { pokok bahasan yang akan disampaikan. Setelah dilakuakn pembelajaran } \\
\text { menggunakan software treker untuk menganalisis vidio viskositas fluida, } \\
\text { mahasiswa diberika post-test untuk mengetahui keberhasilan proses } \\
\text { pembelajaran dan mengukur hasil belajar mahasiswa terhadap materi yang } \\
\text { diajarkan. Berdasarkan hasil penelitian diperoleh skor rata-rata hasil belajar } \\
\text { mengalami kenaikan sebesar } 25 \text { dengan nilai N-gain } 0,63 \text { atau pada katagori } \\
\text { sedang. Hasil tersebut menunjukkan bahwa pembelajaran dengan } \\
\text { menggunakan software tracker dapat meningkatkan hasil belajar mahasiswa } \\
\text { dengan baik. Hal ini juga didukung dengan hasil dari analisis paired sample } \\
\text { t-test diperoleh nilai signifikasi sebesar 0,00, yang memberikan arti bahwa } \\
\text { terdapat pengaruh yang signifikan pada pembelajaran menggunakan bantuan } \\
\text { software treker terhadap hasil belajar fisika mahasiswa pada pokok bahasan } \\
\text { viskositas fluida. }\end{array}$} \\
\hline $\begin{array}{l}\text { Histori Artikel: } \\
\text { Submit: 2022-02-01 } \\
\text { Diterima: 2022-02-01 } \\
\text { Dipublikasikan: 2022-02-03 }\end{array}$ & \\
\hline $\begin{array}{l}\text { Kata Kunci: } \\
\text { Pengaruh; software treker; } \\
\text { hasil belajar }\end{array}$ & \\
\hline & \\
\hline $\begin{array}{l}\text { Jurnal Pendidikan Sains dan } \\
\text { Komputer is licensed under a } \\
\text { Creative Commons Attribution- } \\
\text { NonCommercial } 4.0 \text { International } \\
\text { (CC BY-NC 4.0). }\end{array}$ & \\
\hline
\end{tabular}

\section{LATAR BELAKANG}

Dalam mempelajari fisika kemampuan pemahaman konsep menjadi syarat pokok dalam mencapai keberhasilan pembelajaran. Namun tidak sedikit mahasiswa yang mengalami kesulitan akan hal tersebut, hal ini disebabkan karena banyak mahasiswa yang menganggap pelajaran fisika adalah pelajaran yang rumit dan beranggapan fisika menakutkan, membosankan serta kelas yang monoton (Azizah, et al., 2015). Ketidaktertarikan mahasiswa dalam pelajaran fisika ini berpengaruh buruk. Ini yang menyebabkan rendahnya pemahaman konsep awal dan mengakibatkan hasil belajar rendah (Isnah et al., 2016). Hal ini juga disebabkan karena kurangnya media pembelajaran interaktif yang sesuai dengan kebutuhan mahasiswa (Maryam, 2021).

Pembelajaran fisika akan berhasil jika ditunjang dengan perangkat pembelajaran yang tepat karena hal itu dapat membantu mahasiswa dalam memahami dan menguasai materi Fisika dengan baik (Bao \& Koenig, 2019). Fisika merupakan sebuah ilmu pengetahuan yang sangat erat hubungannya dengan fenomena alam. Dari fenomena alam tersebut dapat dijadikan sumber belajar yang terjadi dalam kehidupan sehari-hari maupun peristiwa fisika yang dikondisikan keadaannya agar diperoleh keadaan yang ideal untuk keperluan penelitian atau pembelajaran. Peristiwa fisika tersebut jika ditampilkan dalam bentuk video, maka disebut sebagai video kejadian fisika. 


\section{Jurnal Pendidikan Sains dan Komputer}

Pembelajaran fisika dengan memanfaatkan video kejadian fisika memunginkan peneliti atau mahasiswa untuk menggali konsep fisika melalui kegiatan analisis. Analisis video kejadian fisika merupakan kegiatan analisis yang dilakukan pada suatu video kejadian fisika untuk memahami konsep yang terdapat pada video kejadian fisika tersebut. Beberapa contoh peneliti yang melakukan penelitian tentang analisis video kejadian fisika diantaranya: (Ramli et al., 2016) menganalisis video gerak osilasi sederhana, (Nurfadilah et al., 2020) menganalisis moment inersia, (Suwarno, 2017) menganalisis video pada gerak melingkar, dan (Poonyawatpornkul \& Luksameevanish, 2018) menganalisis video gerak benda pada bidang miring. Dari berbagai penelitian tersebut dapat disimpulkan bahwa analisis video kejadian fisika juga berguna untuk membantuk dalam pembelajaran serta untuk membuktikan konsep yang ada pada kejadian fisika diperistiwa nyata terhadap teori yang ada, sehingga fisika dapat lebih dipahami secara kontekstual.

Salah satu tool yang bisa digunakan untuk menganalisis video adalah software tracker dan ini bisa menjadi solusi pembelajaran di abad ke-21 (Nurmayanti et al., 2019). Software tracker dirancang untuk pembelajaran Fisika yang menyediakan bayangan dari video yang cocok digunakan untuk mengantarkan konsep-konsep Fisika dengan menghasilkan data hasil track yang tepat dan akurat (Susanti \& Asmoro, 2019). Pembelajaran dengan menggunakan software tracker merupakan ide yang bagus untuk dikembangkan dalam pembelajaran Fisika terutama jika peralatan laboratorium yang kurang memadai metode ini dapat dijadikan sebagai solusi (Asrizal et al., 2018).

\section{a. Software Treker}

\section{STUDI LITERATUR}

Tracker merupakan suatu tool analisis video yang dilengkapi dengan alat pemodelan yang dibangun oleh Java Open Source Physics (Brown \& Cox, 2009). Software tracker dapat diperoleh atau di unduh secara gratis di internet. Treker merupakan software yang dapat digunakan untuk analisis vidio untuk pembelajaran fisika. Program treker dapat digunakan untuk menganalisis berbagai vidio yang berkaitan dengan kinematika dan spektrum cahaya. Fitur yang dimiliki treker antara lain pelacak objek dengan overlay posisi, kecepatan, percepatan, grafik, beberapa kerangka acuan, titik kalibrasi dan profil garis untuk analisis spektrum dan pola interferensi (Prima et al., 2016).

Dalam menggunakan software tracker mahasiswa dapat menganalisis gerak suatu benda yang terdapat dalam video, dengan cara membuat jejak mengikuti gerak benda yang ada dalam video . Software ini sangat membantu mahasiswa dalam memahami konsep materi pembelajaran. Menurut (Eso et al., 2017) kekuatan dari tracker terletak pada kenyataan bahwa seseorang dapat memvisualisasikan konsep tersebut dalam waktu real.

\section{b. Viskositas}

Pada sebuah kejadian dimana sebuah bola berjari-jari R yang dijatuhkan ke dalam fluida mulamula bergerak dipercepat karena gaya gravitasi Bumi, kemudian diperlambat hingga benda bergerak dengan kecepatan konstan dan akhirnya berhenti di dasar fluida. Hal ini terjadi karena bola tersebut tidak hanya mengalami gayaapung dan gaya berat saja, melainkan juga mengalami gaya gesek antara permukaan bola dengan fluida yang disebabkan oleh kekentalan zat cair atau viskositas. viskositas dihasilkan oleh gaya kohesi antara molekul-molekul zat cair dan merupakan ukuran kekentalan suatu 
fluida yang secara kuantitatif dinyatakan dengan besaran koefisien viskositas $\eta$. Semakin besar viskositas, semakin susah suatu zat padat bergerak di dalamnya. Menurut Sir George Stokes, gaya gesek $(F s)$ yang dialami oleh suatu bola berjari-jari $\mathrm{R}$ adalah

$$
F s \square 6 \square \square R v
$$

dengan Fs merupakan gaya Stokes, $\square \square \square$ merupakan koefisien viskositas, $R$ jari-jari bola,dan $v$ kecepatan terminal. Suatu saat bola akan mencapai keadaan setimbang sehingga bergerak dengan kecepatan konstan yang disebut dengan kecepatan terminal. Pada saat ini resultan gayagaya yang bekerja pada bola sama dengan nol, sehingga dapat dinyatakansebagai berikut:

$$
\begin{aligned}
& F a \square F s-m g=0 \\
& F a \square F s=m g
\end{aligned}
$$

Dengan mengetahui kecepatan terminal, nilai koefisien viskositas suatu fluida dapatditentukan yaitu:

$$
\frac{2 g R^{2}\left(\rho_{\text {bola }}-\rho_{\text {fluida }}\right)}{9} \frac{1}{v}
$$

Nilai kecepatan terminal diperoleh melalui analisis video rekaman percobaan menggunakan aplikasi tracker, sedangkan nilai jari-jari, dan massa jenis bola dapat ditentukan melalui pengukuran langsung massa dan volum bola, sedangkan massa jenis fluida diperoleh melalui pengukuran menggunakan hidrometer. Adapun percepatan gravitasi (g) digunakan nilai standar rata-rata percepatan gravitasi Bumi yaitu $9,8 \mathrm{~m} / \mathrm{s}^{2}$. Adapun contoh pembelajaran menggunakan aplikasi treker dalam menganalisis vido bola dijatuhkan kedalam fluida dapat dilihat pada gambar 1 berikut.

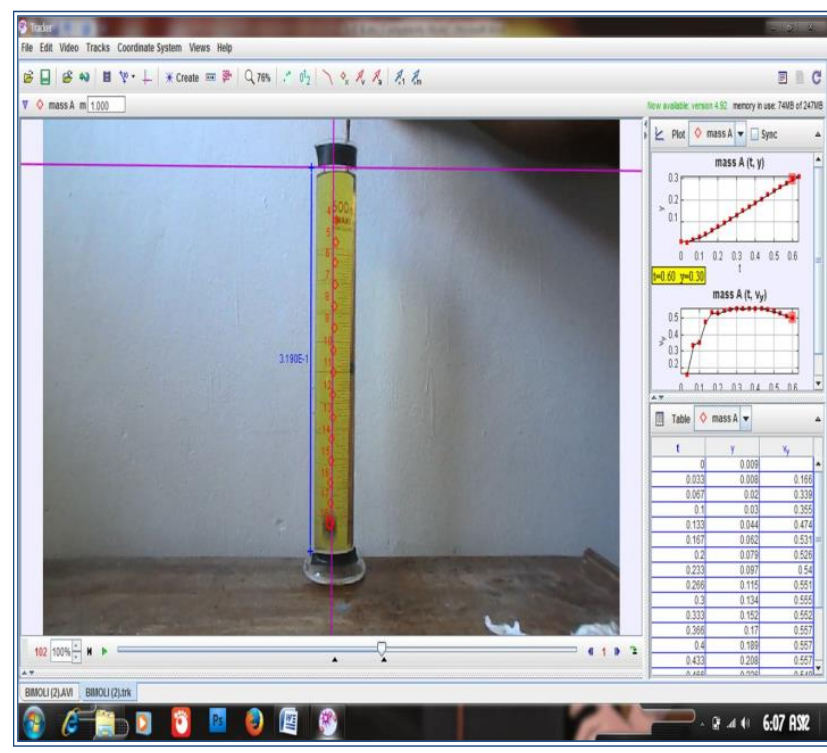

\begin{tabular}{|c|c|c|c|c|}
\hline \multirow{2}{*}{ Fit Name: Line } & \multirow[t]{2}{*}{$\boldsymbol{\nabla}$} & \multirow{2}{*}{ Fit Builder... } & Parameter & Value \\
\hline & & & $a$ & 15.811 \\
\hline \multicolumn{3}{|c|}{ Fit Equabon: $y=a^{4}+b$} & b & 5.852 \\
\hline
\end{tabular}

(a)

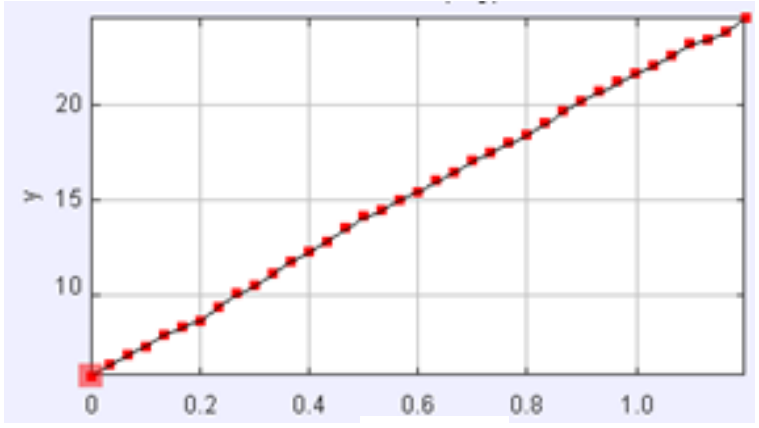

(b) 


\section{Jurnal Pendidikan Sains dan Komputer}

Gambar 1. (a) Lintasan gerak bola yang dijatuhkan hasil analisis software tracker, (b). Tampilan grafik gerak bola yang dijatuhkan, dan (c) persamaan gerak setelah mencapai kecepatan terminal

\section{METODE}

Penelitian ini menggunakan metode eksperimen dengan desain quireksperiment dengan teknik penelitian yang digunakan adalah one group pretest-posttes design. Desain penelitian yang akan digunakan dapat dilihat seperti gambar berikut.

$\begin{array}{lll}\mathrm{O} 1 & \mathrm{X} & \mathrm{O} 2\end{array}$

Gambar 2. Desain eksperimen one group pretest-posttes design

Keterangan:

O1 : Kemampuan awal mahasiswa (pretest)

$\mathrm{O} 2$ : Kemampuan akhir mahasiswa setelah menerima tradment atau perlakuam (posttest)

$\mathrm{X}$ : Penerapan analisis video tracker pada pembelajaran (treatment)

Sampel dalam penelitian ini yaitu mahasiswa semster satu prodi teknika Akademi Maritim Cirebon. Sedangkan teknik pengumpulan data dalam penelitian ini yaitu diperoleh dengan teknik tes tertulis berupa pretest-posttest.. tes dalam penelitian ini yaitu tes dengan jumlah 30 soal dengan rincian 20 soal pilihan ganda dan 10 soal essay. Data pretest diberikan untuk memengetahui kemampuan awal mahasiswa sebelum pembelajaran, sedangkan data posttest diberikan untuk melihat perbedaan atau mengetahui keberhasilan proses pembelajaran dan mengukur hasil belajar mahasiswa terhadap materi yang diajarkan.

Pada penelitian ini teknik analisis data yang digunakan yaitu menggunakan paired sample t-test.. Sebelum dilakukan paired sample t-test, terlebih dahulu dilakukan uji prasyarat yaitu uji normalitas sebagai syarat agar bisa dilakukan paired sample t-test. Dalam penelitian ini uji paired sample t-test menggunakan bantuan software SPSS 16 for windows. Selain itu dalam melakukan analisis data hasil tes belajar juga digunakan analisis $N$-Gain. Gain yaitu selesih data yang diperoleh dari hasil pretest dan posttest. Menurut (Meltzer, 2002) rumus $N$-Gain adalah sebagai berikut.

$$
N-\text { Gain }\langle g\rangle=\frac{\text { skor posttes }- \text { skor pretes }}{\text { skor maksimal-skor pre est }}
$$

Kriteria interpretasi $N$-gain yang ditentukan oleh Meltzer ditujukan pada tabel 1 berikut. 
Tabel 1. Kriteria Interpretasi $N$-gain

\begin{tabular}{cc}
\hline$N$ - gain $\langle g\rangle$ & Kriteria Interpretasi \\
\hline$\langle g\rangle>0,7$ & Tinggi \\
$0,3 \leq\langle g\rangle \leq 0,7$ & Sedang \\
$\langle g\rangle<0,3$ & Rendah \\
\hline
\end{tabular}

\section{HASIL}

Penelitian ini bertujuan untuk mengetahui pengaruh penggunaan software treker terhadap hasil belajar fisika mahasiswa pada pokok bahasan viskositas fluida. Sebelum instrumen tes pretest dan posttest digunakan dalam tahap pelaksanaan penelitian, instrumen diuji terlebih dahulu pada kelas lain untuk mengetahui kelayakan instrumen sebelum digunaka untuk penelitian. Pada mulanya julah instrumen soal yang diujikan yaitu berjumlah 30 soal. Berdasarkan hasil uji instrumen pada tahap uji dayabeda dan taraf kesukaran soal dari 30 soal semua pada katagori baik, akan tetapi pada uji validitas dan reliabilitas, dari 30 soal yang diuji validitas hanya 25 soal yang valid dan 5 soal tidak valid. Sehingga hanya 25 soal yang digunakan dalam penelitian. Adapun hasill belajar pretest dan post-test hasil belajar mahasiswa dapat dilihat pada tabel 2 berikut.

Tabel 2. hasill belajar pretest dan post-test hasil belajar mahasiswa

\begin{tabular}{lcclcc}
\hline Rentang & $\begin{array}{c}\text { Frekunsi } \\
\text { Pre-test }\end{array}$ & $\begin{array}{c}\text { Frekunsi } \\
\text { Post-test }\end{array}$ & \multicolumn{1}{c}{ Statistik } & Pre-test & Post-test \\
\hline Sangat Baik ( 85-100) & 0 & 21 & Skor Terendah & 40 & 76 \\
Baik ( 70-84) & 2 & 14 & Skor Tertinggi & 76 & 100 \\
Cukup (55-69) & 25 & 0 & Mean (rata-rata) & 60 & 85 \\
Kurang (40-54) & 8 & 0 & Median & 60 & 88 \\
Sangat Kurang ( 0-39) & 0 & 0 & Modus & 56 & 96 \\
\hline
\end{tabular}

Berdasarkan tabel 2 dapat diketahui bahwa hasil belajar mahasiswa pada pretes, kemampuan kognitif mahasiswa rata-rata berada pada kemampuan cukup dan dengan nilai baik atau pada rentang 7084 terdapat 2 mahasiswa, 25 pada kata gori cukup atau pada rentang 55-69 dan 8 mahasiswa pada katagori kurang atau pada rentang 40-54. Sedang pada hasil post-test mahasiswa rata-rata kemampuan kognitifnya mengalami peningktan atau pada kata gori sangat baik yaitu pada rentang 85-100 terdapat 21 mahasiswa dan dengan sekor terendah 76 ada 14 mahasiswa yang berarti semua mahasiswa memenuhi kreteria ketuntasan minimal (KKM). Pengaruh penggunaan software tracker terhadap hasil belajar mahasiswa dapatdilihat dari uji N-Gain yang mana di dapat dari nilai pretest dan posttest. Rata-ratanilai 


\section{Jurnal Pendidikan Sains dan Komputer}

pretest siswa 60 dan posttes 85. Dari hasil tersebut dapat dilihat bahwaterjadi peningkatan nilai rata-rata mahasiswa sebelum diberikan perlakuan dengan pembelajaran menggunakan softwsre tracker dan setelah diberi perlakuan menggunakan softwsre tracker. Hasil ujiN-Gain dapat dilihat pada perhitungan berikut.

$$
N-\operatorname{Gain}\langle g\rangle=\frac{85-60}{100-60}=0,63
$$

Hasil uji N-Gain tersebut bernilai 0,63 yang masuk dalam kategori sedang. Setah itu data hasil pretest dan post-test dilakukan uji normalitas data sebagai sarat dilakukan uji paired sample t-test. Adapun hasil uji normalitas data pretest dan post-test dapat dilihat pada tabel 3 berikut.

Tabel 3. Rangkuman Hasil Uji Normalitas Pre-test dan Post-test Hasil Belajar Fisika

\begin{tabular}{cccc}
\hline Data & $\begin{array}{c}\text { Kolmogorov- } \\
\text { Smirnov }\end{array}$ & $\begin{array}{c}\text { Asymp Sig } \\
\text { (2-tailed) }\end{array}$ & Kesimpulan \\
\hline Pre-test Hasil Belajar & 0,703 & 0,553 & Berdistribusi Normal \\
Post-test Hasil Belajar & & & Berdistribusi Normal \\
& 0,869 & 0,612 & \\
\hline
\end{tabular}

Berdasarkan pada tabel 3, pada kelas eksperimen diperoleh nilai Asymp Sig KolmogorovSmirnov pre-test hasil belajar sebesar 0,553>0,05 dan post-test hasil belajar 0,612 >0,0. Hasil tersebut menunjukkan data pre-test dan post-test kelas eksperimen dan kelas kontrol berdistribusi normal. Setelah data berdistribusi normal kemudian dilakuakan uji paired sample t-test.untuk mengetahi hasil hipotesis Pada analisis uji paired sample t-test ini, menggunakan bantuan dari software SPSS. Hipotesis yang diujikan yaitu $H_{o}=$ penggunaan software tracker tidak berpengaruh terhadap hasil belajar mahasiswa dan $\mathrm{Ha}=$ penggunaan software tracker berpengaruh terhadap hasil belajar mahasiswa. Kriteria pengujian yaitu jika apabila Sig $>0,05$ maka Ho diterima, atau $t_{\text {hitung }}<t_{\text {tabel }}$ dan jika nilai $\operatorname{Sig}<0,05$ atau $t_{\text {hitung }}>$ $\mathrm{t}_{\text {tabel }}$ maka Ho ditolak. Adapun hasil uji paired sample t-test menggunakan software SPSS dapat dilihat pada tabel 4 berikut.

Tabel 4. Hasil uji paired sample t-test

\begin{tabular}{lcccccc}
\hline \multirow{2}{*}{$\begin{array}{l}\text { pretest } \\
\text { posttest }\end{array}$} & - & \multicolumn{5}{c}{ Paired Differences } \\
\cline { 2 - 7 } & Mean & Std. Deviation & Std. Error Mean & t & Df & Sig.(2-tailed) \\
\cline { 2 - 7 } & 21,3 & 10,3 & 2,1 & 8,16 & 35 & 0,000 \\
\hline
\end{tabular}

Berdasarkan tabel 4 dapat diketahi nilai sinifikansi dari uji paired sample t-test dengan menggunakan software SPSS diperoleh nilai Sig $<0,05$ yang artinya $H_{o}$ ditolak dan $H$ a diterima atau enggunaan 


\section{Jurnal Pendidikan Sains dan Komputer}

software tracker berpengaruh terhadap hasil belajar mahasiswa.

\section{KESIMPULAN}

Berdasarkan dari hasil penelitian pengaruh penggunaan software treker terhadap hasil belajar fisika mahasiswa pada pokok bahasan viskositas fluida didapatkan kesimpulan bahwa Penggunaan software tracker pada pembelajaran viskositas fluida berpengaruh signifikan terhadap hasil belajar mahasiswa. Peningkatan hasil belajar mahasiswa ditunjukkan dengan hasil N-gain sebesar 0,63 yang masuk dalam kategori sedang. Hasil dari analisis tersebut didukung denganuji paired sample t-test yang mana hasilnya adalah $0,00<0,05$ artinya terdapat pengaruh.

\section{REFERENSI}

Asrizal, A., Yohandri, Y., \& Kamus, Z. (2018). Studi Hasil Pelatihan Analisis Video dan Tool Pemodelan Tracker pada Guru MGMP Fisika Kabupaten Agam. Jurnal Eksakta Pendidikan (Jep), 2(1), 41. https://doi.org/10.24036/jep/vol2-iss1/84

Azizah, R., Yuliati, L., \& Latifah, E. (2015). Myxoedema ascites. Jurnal Pendidikan Fisika Dan Aplikasinya (JPFA), 5(2), 44-50. https://doi.org/10.1136/pgmj.53.620.343

Bao, L., \& Koenig, K. (2019). Physics education research for 21st century learning. Disciplinary and Interdisciplinary Science Education Research, 1(1), 1-12. https://doi.org/10.1186/s43031-019-00078

Brown, D., \& Cox, A. J. (2009). Innovative Uses of Video Analysis. The Physics Teacher, 47(3), 145150. https://doi.org/10.1119/1.3081296

Eso, R., Kasmiati, S., Amiruddin, T., \& Mursyid, A. (2017). Simulation of Terminal Velocity and Viscosity of Fluid Using. 5(10), 165-172.

Isnah, S., Muhammad, A., \& Maruf. (2016). Jurnal Pendidikan Fisika Universitas Muhammadiyah Makassar Meningkatkan Hasil Belajar Fisika Melalui Model Pembelajaran. Jurnal Pendidikan Fisika, 4(1), 249-264. http://journal.unismuh.ac.id/index.php/jpf/article/view/303

Maryam, E. (2021). Pengaruh Software Modellus Sebagai Media Simulasi Virtual Terhadap Kemampuan Berpikir Kreatif Mahasiswa. Silampari Jurnal Pendidikan Ilmu Fisika, 3(2), 144-157.

Meltzer, D. E. (2002). The relationship between mathematics preparation and conceptual learning gains in physics: A possible "hidden variable" in diagnostic pretest scores. American Journal of Physics, 70(12), 1259-1268. https://doi.org/10.1119/1.1514215

Nurfadilah, Sulisworo, D., \& Maruto, G. (2020). Tracker Application to Determine the Moment of Inertia in a Video-Based Laboratory to Improve Students' Learning Activity. 477(Iccd), 538-541. https://doi.org/10.2991/assehr.k.201017.119

Nurmayanti, D., Jumadi, J., Wilujeng, I., \& Kuswanto, H. (2019). Developing of Learning Instruments based on Software Tracker in Measuring Cognitive Learning Outcomes. Journal of Physics: Conference Series, 1233(1). https://doi.org/10.1088/1742-6596/1233/1/012047 
Poonyawatpornkul, J., \& Luksameevanish, V. (2018). High Speed Video Technique Analysis of an Object Moving on an Inclined Plane. 15(2), 16-24.

Prima, E. C., Mawaddah, M., Winarno, N., \& Sriwulan, W. (2016). Kinematics investigations of cylinders rolling down a ramp using tracker. AIP Conference Proceedings, 1708(February 2016). https://doi.org/10.1063/1.4941183

Ramli, M. H., Chan, K. T., \& Yap, W. F. (2016). Study of Simple Pendulum Using Tracker Video Analysis and High Speed Camera: A Interactive Approach to Analyze Oscillatory Motion. Solid State Science and Technology, 24(2), 297-305. http://journal.masshp.net

Susanti, H., \& Asmoro, C. P. (2019). Rekonstruksi Set Alat Percobaan Viskositas. Jurnal Wahana Pendidikan Fisika, 4(1), 31-36.

Suwarno, D. U. (2017). Analysis of rotating object using video tracker. Journal of Science \& Science Education, 1(2), 75-80. https://doi.org/10.24246/josse.v1i2p75-80 